\title{
TRICYCLOHEXYLPHOSPHINE COMPLEXES OF RHODIUM(I), RHODIUM(II), IRIDIUM(I) AND IRIDIUM(III)
}

\author{
F. G. MOERS, J. A. M. DE JONG and P. M. H. BEAUMONT \\ Department of Inorganic Chemistry, University of Nijmegen, Toernooiveld, Nijmegen, \\ The Netherlands
}

(Received 8 August 1972)

\begin{abstract}
The preparation of iridium and rhodium complexes with tricyclohexylphosphine $\left(\mathrm{PCy}_{3}\right)$ is reported. Paramagnetic rhodium(II) complexes of the type $\mathrm{RhX} \mathrm{X}_{2}\left(\mathrm{PCy}_{3}\right)_{2}$ with $\mathrm{X}=\mathrm{Cl}$ or $\mathrm{Br}$ were prepared. The reaction between iridium salts with $\mathrm{PC}_{y_{3}}$ in propanol-2 resulted in diamagnetic complexes with iridium halogenide ratio $1: 2$. The possible structures of these compounds are discussed. Complexes of the type $\mathrm{MCl}(\mathrm{CO})\left(\mathrm{PCy}_{3}\right)_{2}$ with $\mathrm{M}=\mathrm{Rh}$ or $\mathrm{Ir}$ and $\mathrm{IrHCl}_{2}(\mathrm{CO})\left(\mathrm{PCy}_{3}\right)_{2}$ are described and characterized.
\end{abstract}

\section{INTRODUCTION}

IN PREVIOUs communications we described the preparation of stable complexes of tricyclohexylphosphine with copper(I), ruthenium(II) and osmium(II)[1-3]. The copper complexes with this ligand have a different structure in comparison to other copper phosphine complexes. The hydrido carbonyl complexes of osmium and ruthenium with the formula $\mathrm{MHCl}(\mathrm{CO})\left(\mathrm{PCy}_{3}\right)_{2}$ show a hydrogen deuterium exchange of the cyclohexyl groups of the phosphine. Different behaviour of these complexes with $\mathrm{PCy}_{3}$ as ligand in comparison with other phosphine complexes may be due to the steric hindrance of the bulky cyclohexyl groups [1,4] and to the strongly basic nature of this ligand [5]. The reaction of rhodium and iridium halide compounds with substituted phosphine in alcohols or benzene give products

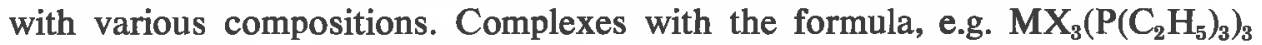
with $\mathrm{M}=\mathrm{Rh}$ or Ir and $\mathrm{X}=\mathrm{Cl}$ or $\mathrm{Br}[6,7], \mathrm{RhCl}_{2}\left(\mathrm{P}\left(o-\mathrm{CH}_{3} \mathrm{C}_{6} \mathrm{H}_{4}\right)_{3}\right)_{2}[8], \mathrm{RhCl}_{2}(\mathrm{P}(t-$ $\left.\left(\mathrm{C}_{4} \mathrm{H}_{9}\right)_{2} \mathrm{C}_{2} \mathrm{H}_{5}\right)_{2}$ [9], and $\mathrm{IrHCl}_{2}\left(\mathrm{PPh}_{3}\right)_{3}$ and $\mathrm{IrHCl}_{2}\left(\mathrm{PPh}_{3}\right)_{2}[10]$ have been obtained.

The present study describes rhodium and iridium complexes with the general formula $\mathrm{MX}_{2}\left(\mathrm{PCy}_{3}\right)_{2}, \mathrm{MCl}(\mathrm{CO})\left(\mathrm{PCy}_{3}\right)_{2}$ and $\mathrm{MHCl}_{2}(\mathrm{CO})\left(\mathrm{PCy}_{3}\right)_{2}$ with $\mathrm{X}=\mathrm{Cl}, \mathrm{Br}$ and $\mathrm{M}=\mathrm{Rh}$ or $\mathrm{Ir}$.

1. F. G. Moers and P. H. op het Veld, J. inorg. nucl. Chem. 22, 3225 (1970).

2. F. G. Moers, Chem. Comm. 2, 79 (1971).

3. F. G. Moers and P. J. Langhout, Recl. Trav. Chim. Pays. Bas. 91, 591 (1972).

4. P. L. Bellon, V. Albano, V. D. Bianco, F. Pompa and V. Scatturin, Ric. Sic., Rend. ser. A3, 1213 (1963); Chem. Abstr. 14106a (1964).

5. W. Stromeier and T. Onoda, Z. Naturf. 23B, 1377 (1969).

6. J. Chatt, A. E. Field and B. L. Shaw, J. chem. Soc. 3371 (1963).

7. J. Chatt, N. P. Johnson and B. L. Shaw, J. chem. Soc. 2508 (1964).

8. M. A. Bennett and P. A. Longstaff, J. Am. chem. Soc. 91, 6266 (1969).

9. C. Masters and B. L. Shaw, J. chem. Soc (A), 3679 (1971).

10. A. Araneo and S. Martinengo, Gazz. chim. ital. 61 (1965). 


\section{EXPERIMENTAL}

Preparation of tricyclohexylphosphine

The ligand was prepared as described by Issleib et al. [11].

Rhodium and iridium salts

All the platinum metal halides were commercially available from Fa. Drijfhout.

Preparation of the complexes $\mathrm{RhX}_{2}\left(\mathrm{PCy}_{3}\right)_{2}$ with $\mathrm{X}=\mathrm{Cl}$ or $\mathrm{Br}$

A solution of 1 mmole $\mathrm{RhX}_{3} \cdot 3 \mathrm{H}_{2} \mathrm{O}$ in propanol-2 was added with stirring to a solution of $5 \mathrm{~m}$-mole $\mathrm{PCy}_{3}$ in $50 \mathrm{ml}$ propanol-2 in an atmoshpere of nitrogen at $25^{\circ} \mathrm{C}$ for $48 \mathrm{hr}$. The precipitate was filtered, washed with water and propanol-2 and dried in vacuum over $\mathrm{P}_{2} \mathrm{O}_{5}$.

The complexes $\mathrm{IrX}_{2}\left(\mathrm{PCy}_{3}\right)_{2}$ were prepared on a similar way by reaction of an aqueous solution of $\mathrm{Na}_{3} \mathrm{IrX}_{6}, \mathrm{PCy}_{3}$ and propanol-2 for $24 \mathrm{hr}$ at $70^{\circ} \mathrm{C}$.

\section{Preparation of the pyridine complex $\mathrm{IrCl}_{2}\left(\mathrm{PCy}_{3}\right)_{2}(\mathrm{py})$}

The pyridine adduct was prepared by addition of an excess pyridine with stirring to a solution of $\mathrm{IrCl}_{2}\left(\mathrm{PCy}_{3}\right)_{2}$ in chloroform under a nitrogen atmosphere. The mixture was stirred for $12 \mathrm{hr}$ at room temperature. The yellow precipitate was filtered, washed with propanol-2 and dried in a high vacuum.

\section{Preparation of the complex $\mathrm{IrCl}(\mathrm{CO})\left(\mathrm{PCy}_{3}\right)_{2}$}

Carbon monoxide was passed through a boiling solution of $\mathrm{K}_{\mathbf{3}} \mathrm{IrCl}_{\mathbf{6}}$ in diethleneglycol for $2 \mathrm{hr}$ with continuous stirring. After cooling to $70^{\circ} \mathrm{C}$ an ethanolic solution of $4 \mathrm{~m}$-mole $\mathrm{PCy}_{3}$ was added. The black precipitate was extracted with a toluene-chloroform mixture, and yellow needles were formed on cooling the solution.

\section{Preparation of the complex $\mathrm{RhCl}(\mathrm{CO})\left(\mathrm{PCy}_{3}\right)_{2}$}

After passing carbon monoxide through a boiling solution of $2 \mathrm{~m}$-mole $\mathrm{RhCl}_{3} \cdot 3 \mathrm{H}_{2} \mathrm{O}$ in ethanol for $30 \mathrm{~min}$ an ethanolic solution of $4 \mathrm{~m}$-mole $\mathrm{PCy}_{3}$ was added. The mixture was heated whilst stirring for about $15 \mathrm{~min}$ at $78^{\circ} \mathrm{C}$. Recrystallization of the yellow precipitate was performed with chloroformmethanol mixture.

\section{Preparation of the complexes $\mathrm{IrYCl}_{2}(\mathrm{CO})\left(\mathrm{PCy}_{3}\right)_{2}$ with $\mathrm{Y}=\mathrm{H}$ or $\mathrm{D}$}

Hydrogen- or deuteriumchloride was bubbled through a suspension of $\operatorname{IrCl}(\mathrm{CO})\left(\mathrm{PCy}_{3}\right)_{2}$ in ether for $2 \mathrm{hr}$. The white precipitate was filtered, washed with ethanol and dried in vacuum.

The complex $\mathrm{IrHCl}_{2}(\mathrm{CO})\left(\mathrm{PCy}_{3}\right)_{2} . \mathrm{CHCl}_{3}$ was prepared by adding a concentrated solution of $\mathrm{HCl}$ in water to a saturated solution of $\mathrm{IrCl}(\mathrm{CO})(\mathrm{PCy})_{2}$ in chloroform.

The $\mathrm{DCl}$ gas for preparation of the deuteriated complex was obtained as described by Lux [12].

\section{Physical measurements}

Magnetic susceptibilities were measured on a Gouy balance. A Perkin Elmer 257 spectrophotometer was used for obtaining spectral data in the range $4000-700 \mathrm{~cm}^{-1}$, using the potassium bromide pellet technique. For the range $700-200 \mathrm{~cm}^{-1}$ a Hitachi EPI-L was used with solid samples in cesiumiodide. The $70 \mathrm{eV}$ mass spectra were recorded on a Varian-Atlas SM-1B double focussing instrument under low resolution conditions. The sample, after being introduced into the mass spectrometer by a direct insertion system was heated to $180^{\circ} \mathrm{C}$. Rapid heating and scanning was necessary in order to minimize thermal decomposition for $\mathrm{IrDCl}_{2}(\mathrm{CO})\left(\mathrm{PCy}_{3}\right)_{2}$. Nuclear magnetic resonance spectra were determined with a Varian HA-100 NMR spectrometer. The samples were prepared by dissolving them in deuterated chloroform.

\section{RESULTS AND DISCUSSION}

The new compounds dealt with in the present investigation are listed in Table 1 along with their colours and analytical data. The complexes with the formula $\mathrm{MX}_{2}\left(\mathrm{PCy}_{3}\right)_{2}$ with $\mathrm{M}=\mathrm{Rh}$ or $\mathrm{Ir}$ and $\mathrm{X}=\mathrm{Cl}$ or $\mathrm{Br}$ were formed by reaction of the

11. K. Issleib and A. Brack, Z. anorg. allg. Chem. 227, 258 (1954).

12. H. Lux, Anorganische-chemische Experimentierkunst, 374 (1959). 
Table 1. Analysis data of the complexes

\begin{tabular}{|c|c|c|c|c|c|}
\hline Complex & Colour & $\begin{array}{c}C \\
(\%)\end{array}$ & $\underset{(\%)}{H}$ & $\underset{(\%)}{X}$ & $\underset{(\%)}{N}$ \\
\hline $\mathrm{RhCl}_{2}\left(\mathrm{PCy}_{3}\right)_{2}$ & red-brown & $\begin{array}{c}59.95 \\
(58.85)\end{array}$ & $\begin{array}{c}9.33 \\
(9.06)\end{array}$ & $\begin{array}{c}9 \cdot 26 \\
(9 \cdot 65)\end{array}$ & - \\
\hline $\mathrm{RhBr}_{2}\left(\mathrm{PCy}_{3}\right)_{2}$ & green & $\begin{array}{c}53 \cdot 37 \\
(52 \cdot 50)\end{array}$ & $\begin{array}{c}8 \cdot 42 \\
(8 \cdot 08)\end{array}$ & $\begin{array}{c}19 \cdot 40 \\
(19 \cdot 40)\end{array}$ & - \\
\hline $\mathrm{IrCl}_{2}\left(\mathrm{PCy}_{3}\right)_{\mathbf{2}}$ & rose & $\begin{array}{c}52 \cdot 23 \\
(52 \cdot 48)\end{array}$ & $\begin{array}{c}7 \cdot 94 \\
(8 \cdot 07)\end{array}$ & $\begin{array}{c}8.34 \\
(8 \cdot 61)\end{array}$ & - \\
\hline $\mathrm{IrBr}_{2}\left(\mathrm{PCy}_{3}\right)_{2}$ & brown & $\begin{array}{l}48 \cdot 23 \\
47 \cdot 37\end{array}$ & $\begin{array}{l}7 \cdot 63 \\
7 \cdot 29\end{array}$ & & - \\
\hline $\mathrm{IrCl}_{2}\left(\mathrm{PCy}_{3}\right)_{2} \mathbf{P y}$ & yellow & $\begin{array}{c}54.02 \\
(54.53)\end{array}$ & $\begin{array}{c}8 \cdot 28 \\
(7 \cdot 92)\end{array}$ & $\begin{array}{c}7.91 \\
(7 \cdot 85)\end{array}$ & $\begin{array}{c}1 \cdot 49 \\
(1 \cdot 49)\end{array}$ \\
\hline $\mathrm{IrCl}(\mathrm{CO})\left(\mathrm{PCy}_{3}\right)_{2}$ & yellow & $\begin{array}{c}54 \cdot 34 \\
(54 \cdot 44)\end{array}$ & $\begin{array}{c}8 \cdot 13 \\
(8 \cdot 17)\end{array}$ & & - \\
\hline $\mathrm{RhCl}(\mathrm{CO})\left(\mathrm{PCy}_{3}\right)_{2}$ & yellow & $\begin{array}{c}60 \cdot 84 \\
(61 \cdot 26)\end{array}$ & $\begin{array}{c}8 \cdot 88 \\
(9 \cdot 17)\end{array}$ & $\begin{array}{c}5 \cdot 52 \\
(4 \cdot 89)\end{array}$ & - \\
\hline $\mathrm{IrHCl}(\mathrm{CO})\left(\mathrm{PCy}_{3}\right)_{2}$ & white & $\begin{array}{c}51 \cdot 59 \\
(52 \cdot 10)\end{array}$ & $\begin{array}{c}8 \cdot 13 \\
(7 \cdot 80)\end{array}$ & $\begin{array}{c}7 \cdot 80 \\
(8 \cdot 30)\end{array}$ & - \\
\hline $\mathrm{IrDCl}_{2}(\mathrm{CO})\left(\mathrm{PCy}_{3}\right)_{2}$ & white & $\begin{array}{c}52.74 \\
(52.04)\end{array}$ & $\begin{array}{c}7 \cdot 74 \\
(7 \cdot 79)\end{array}$ & & \\
\hline $\mathrm{IrHCl}_{2}(\mathrm{CO})\left(\mathrm{PCy}_{3}\right)_{2}, \mathrm{CHCl}_{3}$ & white & $\begin{array}{c}46.38 \\
(46.99)\end{array}$ & $\begin{array}{c}7.02 \\
(7.06)\end{array}$ & $\begin{array}{c}17 \cdot 94 \\
(18 \cdot 25)\end{array}$ & \\
\hline
\end{tabular}

Theoretical values are given in parentheses.

M(III) salts with $\mathrm{PCy}_{3}$ in propanol-2. Only a few examples of this type of compound are known $[8,9]$. This composition suggests that in these compounds the metal ion contains the divalent oxidation state with a $d^{7}$-configuration. As should be expected for rhodium (II) compounds the $\mathrm{RhCl}_{2}\left(\mathrm{PCy}_{3}\right)_{2}$ and $\mathrm{RhBr}_{2}\left(\mathrm{PCy}_{3}\right)_{2}$ are paramagnetic with $\mu=2 \cdot 2-2 \cdot 3 \mathrm{~B}$.M. between room temperature and $83^{\circ} \mathrm{K}$, indicating one unpaired electron. The magnetic data are given in Table 2 . The magnetic susceptibility measurements pointed out that in the temperature range from $83-293^{\circ} \mathrm{K}$ the Curie-Weiss law is followed. For the chloride compound a Weiss temperature of $-39^{\circ} \mathrm{K}$ and for the bromide $-24^{\circ} \mathrm{K}$ was found (Fig. 1).

The most important infrared absorption bands are given in Table 3. These compounds show no bands attributable to $\nu \mathrm{Rh}-\mathrm{H}$ or $\nu \mathrm{C}=\mathrm{O}$. In the range 700$200 \mathrm{~cm}^{-1}$ the $\nu \mathrm{RH}-\mathrm{Cl}$ vibrations have been found at $355 \mathrm{~cm}^{-1}$ with a shoulder at $344 \mathrm{~cm}^{-1}$ and the $\nu \mathrm{Rh}-\mathrm{Br}$ at 287 and $268 \mathrm{~cm}^{-1}$. These vibrations lie in the same region as for the corresponding planar palladium compounds. The $\nu \mathrm{Pd}-\mathrm{Cl}$ and $\nu \mathrm{Pd}-\mathrm{Br}$ are found at $350 \mathrm{~cm}^{-1}$ and $284,270 \mathrm{~cm}^{-1}$ respectively [13]. The presence of two metal halogen vibrations should be expected for cis-complexes [14] but sinee in general the $\nu \mathbf{M}-\mathbf{X}$ frequencies are considerably lower than the single $\nu \mathrm{M}-\mathrm{X}$ frequency for the corresponding trans isomer[15] and because of the steric hinderance of the bulky tricyclohexylphosphine, we believe that in these compounds the two halogen atoms are approach trans to each other.

13. Unpublished results.

14. F. G. Moers and J. P. Langhout, Recl. Trav. Chim. Pays. Bas. 89, 1237 (1970).

15. D. M. Adams, Metal-Ligand and Related Vibrations. Edward Amold, London (1967). 
Table 2. Magnetic data after correction for diamagnetism according to Figgis and Lewis*

\begin{tabular}{cccc}
\hline Compound & $\begin{array}{c}\text { Temperature } \\
\left({ }^{\circ} \mathrm{K}\right)\end{array}$ & $\begin{array}{c}\text { Molar suscept. } \\
\times 10^{6},(\mathrm{cgsu})\end{array}$ & $\begin{array}{c}\text { Magnetic } \\
\text { moment }(\mathrm{BM})\end{array}$ \\
\hline $\mathrm{RhCl}_{2}\left(\mathrm{PCy}_{3}\right)_{2}$ & $293 \cdot 5$ & 1877 & $2 \cdot 24$ \\
& 273 & 1929 & $2 \cdot 20$ \\
& 248 & 2121 & $2 \cdot 22$ \\
& 223 & 2313 & $2 \cdot 24$ \\
& 198 & 2539 & $2 \cdot 20$ \\
& 173 & 2854 & $2 \cdot 21$ \\
& 148 & 3308 & $2 \cdot 23$ \\
$\mathrm{RhBr}_{2}\left(\mathrm{PCy}_{3}\right)_{2}$ & 123 & 3779 & $2 \cdot 22$ \\
& 95 & 4878 & $2 \cdot 29$ \\
& 294 & 1931 & $2 \cdot 23$ \\
& 263 & 2088 & $2 \cdot 20$ \\
& 233 & 2353 & $2 \cdot 21$ \\
& 203 & 2825 & $2 \cdot 27$ \\
& 173 & 3195 & $2 \cdot 25$ \\
& 143 & 3774 & $2 \cdot 25$ \\
& 113 & 4630 & $2 \cdot 26$ \\
& $83 \cdot 5$ & 5882 & $2 \cdot 26$ \\
\hline
\end{tabular}

*I. M. Kolthoff and P. J. Elving, Treatise on Analytical Chemistry, Part I, Vol 4, pp. 1778-1781. Interscience, New York (1963).

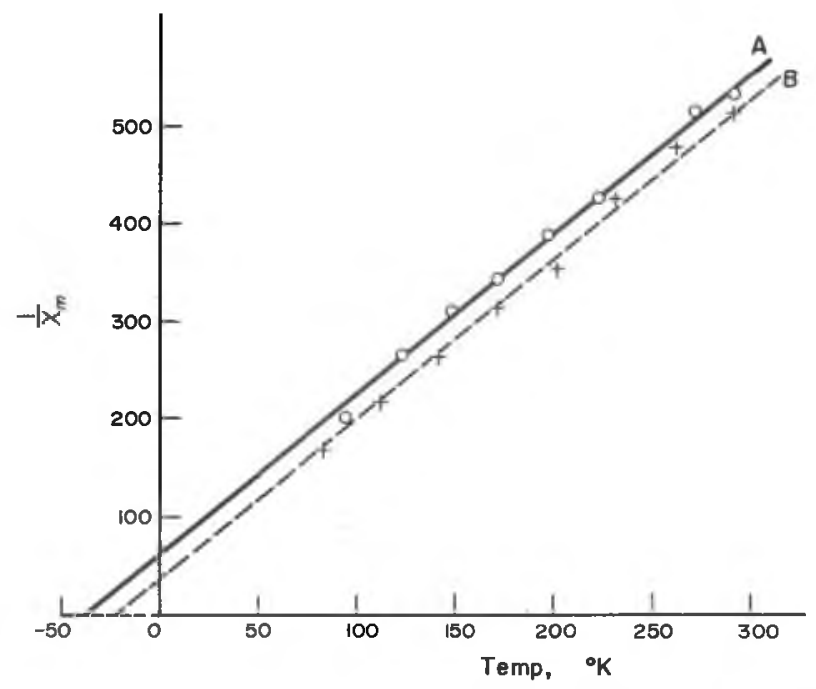

Fig. 1. Temperature dependence of $1 / \chi_{m}$ for $\operatorname{RhCl}_{2}\left(\mathrm{PCy}_{3}\right)_{2}(\mathrm{~A})$ and $\mathrm{RhBr}_{2}\left(\mathrm{PCy}_{3}\right)_{2}(\mathrm{~B})$.

In contrast to the corresponding rhodium compounds the iridium complexes show diamagnetic behaviour, suggesting a low spin $d^{6}$-configuration. This may be explained either by the presence of a hydride ion, resulting in the composition IrHX ${ }_{2}\left(\mathrm{PCy}_{3}\right)_{2}$, or formation of a metal carbon bond by splitting of a hydrogen atom of a cyclohexyl group. In the i.r. spectrum a $\nu$ Ir-H at about $2000 \mathrm{~cm}^{-1}$ was 
Table 3. The major infrared absorption bands $\left(\mathrm{cm}^{-1}\right)$ in the range 4000-200 $\mathrm{cm}^{-1}$

\begin{tabular}{|c|c|c|c|}
\hline Compounds & $\nu \mathrm{CO}$ & $\begin{array}{c}\nu \mathrm{M}-\mathrm{H} \text { or } \\
\nu \mathrm{M}-\mathrm{D}\end{array}$ & $\nu \mathrm{M}-\mathrm{X}$ \\
\hline $\mathrm{RhCl}_{2}\left(\mathrm{PCy}_{3}\right)_{2}$ & - & - & $354(\mathrm{~s}), 343^{\text {sh }}(\mathrm{m})$ \\
\hline $\mathrm{RhBr}_{2}\left(\mathrm{PCy}_{3}\right)_{2}$ & - & - & $288(\mathrm{~m}), 270^{\mathrm{b}}(\mathrm{m})$ \\
\hline $\mathrm{IrCl}_{2}\left(\mathrm{PCy}_{3}\right)_{2}$ & - & - & $317(\mathrm{~s}), 312^{\mathrm{sh}}(\mathrm{m})$ \\
\hline $\operatorname{IrBr}_{2}\left(\mathrm{PCy}_{3}\right)_{2}$ & - & - & $238^{\mathrm{b}}(\mathrm{m})$ \\
\hline $\mathrm{IrCl}_{2}\left(\mathrm{PCy}_{3}\right)_{2}(\mathrm{py})$ & - & - & 303(s) \\
\hline $\mathrm{RhCl}(\mathrm{CO})\left(\mathrm{PCy}_{3}\right)_{2}$ & 1941(s) & - & $305(\mathrm{~s})$ \\
\hline $\mathrm{RhCl}(\mathrm{CO})\left(\mathrm{PPh}_{3}\right)_{2}$ & 1961(s) & - & $315(s)$ \\
\hline $\mathrm{IrCl}(\mathrm{CO})\left(\mathrm{PCy}_{3}\right)_{2}$ & 1931(s) & - & $309(\mathrm{~s}), 304^{\mathrm{sh}}(\mathrm{m})$ \\
\hline $\operatorname{IrCl}(\mathrm{CO})\left(\mathrm{PPh}_{3}\right)_{2}$ & 1944(s) & - & $321(\mathrm{~s})$ \\
\hline $\mathrm{IrHCl}_{2}(\mathrm{CO})\left(\mathrm{PCy}_{3}\right)_{2}$ & $2015(\mathrm{~s})$ & $2276(\mathrm{~m})$ & $310(\mathrm{~s}), 255(\mathrm{~s})$ \\
\hline $\mathrm{IrDCl}_{2}(\mathrm{CO})\left(\mathrm{PCy}_{3}\right)_{2}$ & $2015(s)$ & $1723(\mathrm{~m})$ & $309(\mathrm{~s}), 254(\mathrm{~s})$ \\
\hline $\mathrm{IrHCl}_{2}(\mathrm{CO})\left(\mathrm{PCy}_{3}\right)_{2} \cdot \mathrm{CHCl}_{3}$ & $2012(s)$ & $2270(\mathrm{~m})$ & $302(\mathrm{~s}), 259(\mathrm{~s})$ \\
\hline
\end{tabular}

not observed and the hydrido resonance signal could not be found in the nmr spectrum. The $\nu \mathrm{Ir}-\mathrm{Cl}$ and $\nu \mathrm{Ir}-\mathrm{Br}$ vibrations lie about $15-20 \mathrm{~cm}^{-1}$ lower than the corresponding platinum compounds. The $\nu \mathrm{Pt}-\mathrm{Cl}$ and $\nu \mathrm{Pt}-\mathrm{Br}$ are found at $335,325 \mathrm{~cm}^{-1}$ and $246 \mathrm{~cm}^{-1}$ respectively [13]. Recently a metal carbon bond formation has been found in the rhodium complex $\mathrm{RhCl}_{2}(\mathrm{py})_{2}\left(\mathrm{P}\left(o-\mathrm{C}_{6} \mathrm{H}_{4} \mathrm{Me}\right)_{2} \mathrm{O}-\right.$ $\mathrm{C}_{6} \mathrm{H}_{4} \mathrm{CH}_{2}$ ). $0 \cdot 61 \mathrm{CHCl}_{3}[16]$ and a metal carbon bond formation was also postulated for explaining the hydrogen deuterium exchange in the complex $\mathrm{OsHCl}(\mathrm{CO})$ $\left(\mathrm{PCy}_{3}\right)_{2}$ [3]. These data suggest a metal-carbon bond formation. However in the diamagnetic pyridine complex $\operatorname{IrX} \mathrm{X}_{2}\left(\mathrm{PCy}_{3}\right)_{2}(\mathrm{py})$, prepared by addition of pyridine to $\operatorname{IrX}_{2}\left(\mathrm{PCy}_{3}\right)_{2}$, a weak absorption band has been found at $2160 \mathrm{~cm}^{-1}$. This may be assigned to a $\nu \mathrm{Ir}-\mathrm{H}$ vibration. A dimeric formula of the complex $\operatorname{IrX} \mathrm{X}_{2}\left(\mathrm{PCy}_{3}\right)_{2}$ with hydrogen bridge atoms may not be excluded. Identification of $\nu \mathrm{Ir}-\mathrm{H}$ vibrations with the hydrogen atom as bridge at about $1200 \mathrm{~cm}^{-1}$ [17] was not possible because of overlap of phosphine absorption bands in this region. It may also be possible that the complex is a $\operatorname{Ir}(\mathbf{I}), \operatorname{Ir}(\mathrm{III})$ compound with the structure:

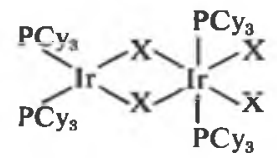

Distinguishing between the possible structure of the iridium-compounds with $\mathrm{X}$-ray structure deterimination meets with difficulties because suitable crystals have not yet been obtained.

The complex $\mathrm{IrCl}(\mathrm{CO})\left(\mathrm{PCy}_{3}\right)_{2}$ was prepared according to Stromeier[5] with some modification, which are described in the experimental part. The rhodium complex $\mathrm{RhCl}(\mathrm{CO})\left(\mathrm{PCy}_{3}\right)_{2}$ was obtained on a similar way by passing carbon monoxide through a boiling mixture of $\mathrm{RhCl}_{3} \cdot 3 \mathrm{H}_{2} \mathrm{O}$ and $\mathrm{PCy}_{3}$ in ethanol for 40 16. R. Mason and A. D. C. Towl, J. chem. Soc. (A), 1601 (1970).

17. P. M. Maitlis, C. White, D. S. Gill, J. W. Kang and H. B. Lee, Chem. Comm. 2, 734 (1971). 
min. The i.r. spectra show a very intense absorption band at about $1900 \mathrm{~cm}^{-1}$ due to a carbonyl stretching mode of vibration (Table 3). We have found for these complexes a decrease of the $\nu \mathrm{C}=\mathrm{O}$ stretching frequencies in comparison with the complexes with $\mathrm{PPh}_{3}$ as ligand [18, 19]. This may be explained assuming the ligand $\mathrm{PCy}_{3}$ to be a better $\sigma$-donor and poorer $\pi$-back acceptor. This results in an increase of the basisity of the metal[20]. The transition metals generally become more basic going down a group [20]. In agreement with this we found a higher frequency for the $\nu \mathrm{C}=\mathrm{O}$ stretching vibration in the rhodium complex than for the iridium complex.

The complex $\mathrm{IrHCl}_{2}(\mathrm{CO})\left(\mathrm{PCy}_{3}\right)_{2}$ was easily prepared by addition of $\mathrm{HCl}$ to a saturated solution of $\operatorname{IrCl}(\mathrm{CO})\left(\mathrm{PCy}_{3}\right)_{2}$ in ether. Performing the reaction in chloroform as solvent, the solvated complex $\mathrm{IrHCl}_{2}(\mathrm{CO})\left(\mathrm{PCy}_{3}\right)_{2} \cdot \mathrm{CHCl}_{3}$ was isolated. The deuteriated complex $\mathrm{IrDCl}_{2}(\mathrm{CO})\left(\mathrm{PCy}_{3}\right)_{2}$ was prepared with $\mathrm{DCl}$. In the mass spectra we found the parent ion with the lowest fragment ion having $\mathrm{m} / \mathrm{e} 851$ which is in agreement with the formula ${ }^{191} \mathrm{IrD}^{35} \mathrm{Cl}_{2}(\mathrm{CO})\left(\mathrm{PCy}_{3}\right)_{2}$. The i.r. spectrum for the complex $\mathrm{IrHCl}(\mathrm{CO})\left(\mathrm{PCy}_{3}\right)_{2}$ in the range $2300-2000 \mathrm{~cm}^{-1}$ shows one band attributable to $\nu \mathrm{CO}$ stretching at $2015 \mathrm{~cm}^{-1}$ and one band at $2276 \mathrm{~cm}^{-1}$ assigned to $\nu \mathbf{M}-\mathbf{H}$. In the deuteriated complex the expected frequency shift for a covalent iridium hydrogen bond was found $\left(\nu \mathrm{M}-\mathrm{D}\right.$ at $\left.1723 \mathrm{~cm}^{-1}\right)$. The $\nu \mathrm{CO}$ remains unshifted in the deuteride, indicating no resonance interaction between the vibrational states of metal-hydrogen and carbonyl stretching motions. This suggests that the hydrogen and carbonyl are cis to another [21]. The $\nu \mathrm{Ir}-\mathrm{H}$ is so high that the hydrogen is probably trans to chlorine. One $\nu \mathrm{Ir}-\mathrm{Cl}$ has been found near $310 \mathrm{~cm}^{-1}$, indicating that one halide is trans to $\mathrm{CO}$ in the adduct. These observations point to the structure with the following figuration as most probable:<smiles>O=C[Te](Cl)(Cl)(Cl)(Cl)[Ge]</smiles>

A similar structure around iridium(III) was also proposed for the complex with triphenylphosphine as ligand [22]. The complex $\mathrm{RhCl}(\mathrm{CO})(\mathrm{PCy})_{2}$ reacts with $\mathrm{HX}$, but pure compounds with the formula $\mathrm{RhHXCl}(\mathrm{CO})\left(\mathrm{PCy}_{3}\right)_{2}$ could not be isolated. The reaction is very slow and after passing of $\mathrm{HX}$-gas for $8 \mathrm{hr}$ under various conditions the end product always contains $\mathrm{RhCl}(\mathrm{CO})(\mathrm{PCy})_{2}$ as indicated by the i.r. spectrum.

Acknowledgement-The authors wish to thank Professor Dr. Ir. J. J. Steggerda for discussions, Mr. J. P. M. Langhout for experimental assistance and Mr. J. Diersman for performing the elemental analyses.

18. L. Vaska and J. W. Diluzio, J. Am. chem. Soc. 83, 2784 (1961).

19. J. Chatt and B. L. Shaw, J. chem. Soc. (A), 1437 (1966).

20. D. F. Shriver, Acc. chem. Res. 73, (1966).

21. L. Vaska, J. Am. chem. Soc. 88, 4100 (1966).

22. L. Vaska, J. Am. chem. Soc. 88, 5326 (1966). 